\title{
Utilizing Hydraulic Barriers to Reduce Leakage of Hot Water and Enhance Sulphur Production at Mishraq Mine Northern Iraq
}

\author{
Thabit D. Mahder - Bashi \\ Geology Department \\ College of Science \\ Mosul University
}

(Received 13/5/2009, Accepted 25/8/2009)

\begin{abstract}
Sulphur is produced at Mishraq mine by hydrodynamic method (modified Frasch method) of injecting super - heated water $165^{\circ} \mathrm{C}$ through a special well in to the sulphur horizons to melt the sulphur underground.

A seepage of super-heated water at $132^{\circ} \mathrm{C}$ to the Tigris River has been noticed, which cause drop in deposit pressure as well as polluting the river water. A drop of sulphur productivity has also been noticed in some regions of the mine despite of their content of high sulphur percentage, and injection of huge quantities of hot water.

Hydraulic barriers were located according to the transmissibility and temperature distribution maps.

The barriers consist of wells especially designed for injection of cold water down to the sulphur horizons. The barriers were shown to be very effective in increasing the ground water pressure and decreasing the hot water seepage to the river, and dropped the general hot water factor $\left(\mathrm{m}^{3}\right.$ water/1 ton sulphur), from 20.0 to 12.0 ; besides, the productivity of sulphur increased from $1.5 \mathrm{ton} / \mathrm{hr}$ to $5 \mathrm{ton} / \mathrm{hr}$.
\end{abstract}

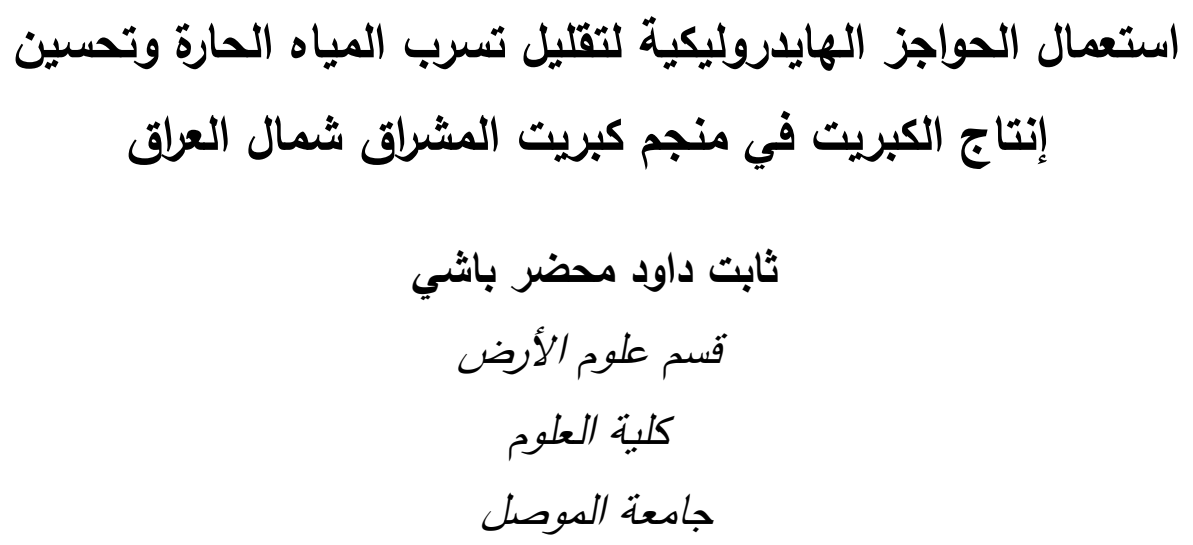




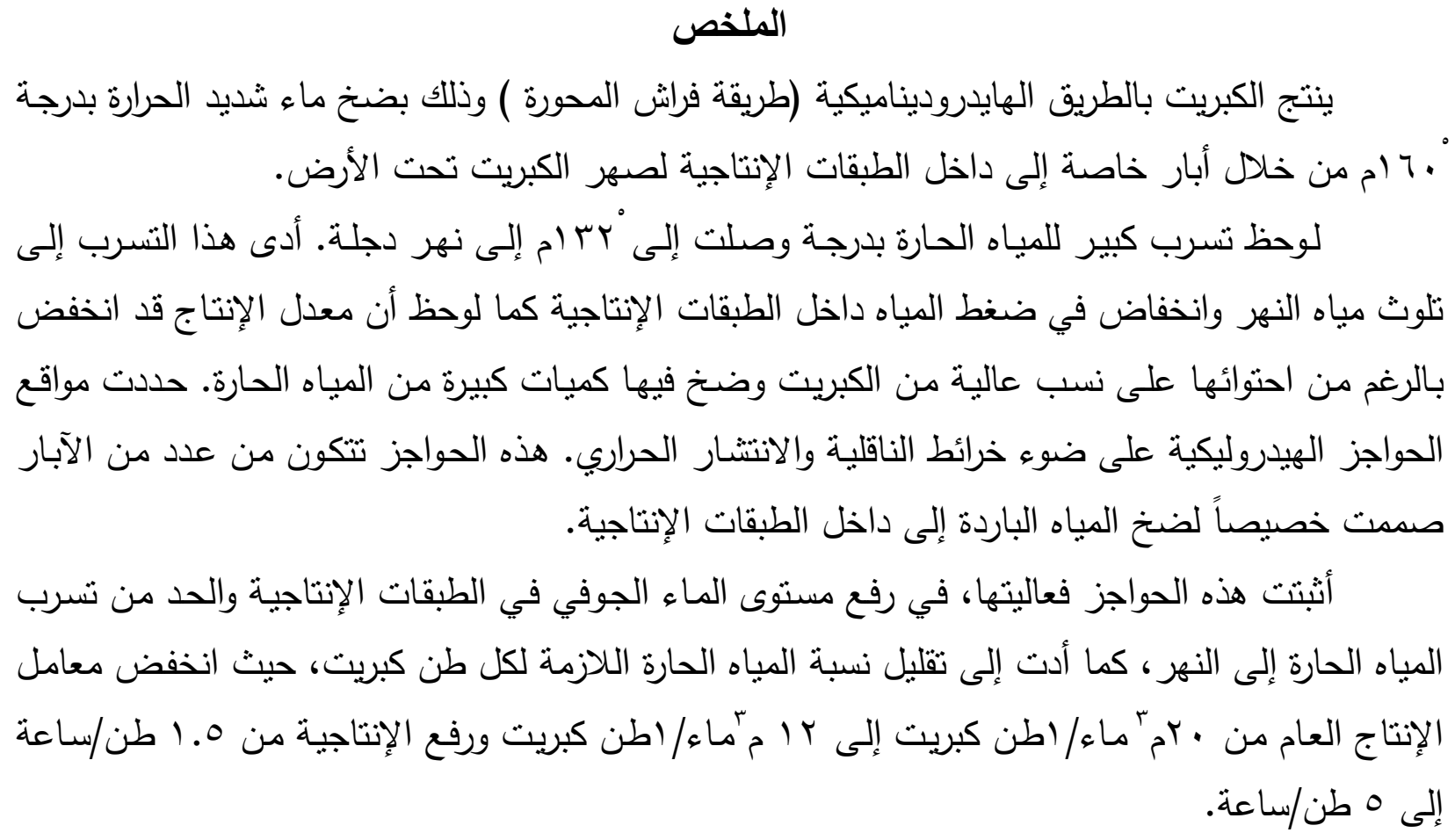

\section{INTRODUCTION}

Mishraq sulphur deposit is located a bout $45 \mathrm{~km}$ to the south of Mosul city, converting an area of about $11 \mathrm{~km}^{2}$. Tigris river and Greater Zab flow through the study area and divided it into three regions called $M_{1}, M_{2}$ and $M_{3}$ as shown in ( Fig. 1).

Mishraq structure forming a brachy anticline with general trend NW - SE, asymmetric to the NE and plunging gently toward SE, having en-chelon nature with the surrounding structure (Centrozap Co., 1971).

The beds of the upper part of the eastern limb and southeastern limb have been eroded by the westward migration of Tigris river and induced by its confluence (Featherstone and AL-Samarrie, 1974).

$\mathrm{AL}$ - Fatha formation (Middle Miocene) dominated the rocks underlying the study area. This formation comprises a series of repetitive cycles, the number of these cycles ranging from 10 to 16 (Mahder-Bashi, 1986) each cycle has arhymic sequence with thickness of less than $1 \mathrm{~m}$ to more than $20 \mathrm{~m}$. A complete cycle consist of clay, marl, limestone and gypsum(Jassim and Goff, 2006), most of these cycles are incomplete with one or more members, are missing (Fig. 2). Replacement of gypsum and anhydrite by recrystalized sulpherous limestone appears to have taken place most commonly in the lower most cycles which is called the productive series where the sulphur being mined (Centrozap Co., 1971). Faulting within the area is common, and characterized by the occurrence of different types of faults. These faults are interpreted from the exploration boreholes records with particular evidence of the presence of breccia and missing or 
repetition of one or more of horizons comprising the AL - Fatha formation. Most of the faults are normal with displacement varying from a few meters to a bout 30m (Mahder-Bashi, 1986).

Frasch method being used for mining the sulphur, which involves the melting of sulphur under ground using super-heated water at $160^{\circ} \mathrm{C}$ injected through a special wells called production wells designed for this purpose. super hated water is put down to sulphur beds under pressure of $10 \mathrm{~atm}$. The molten sulphur is rises up to the surface by compressed air, while the hot water flows through the caverns, fractures and the fault planes see (Fig. 3).

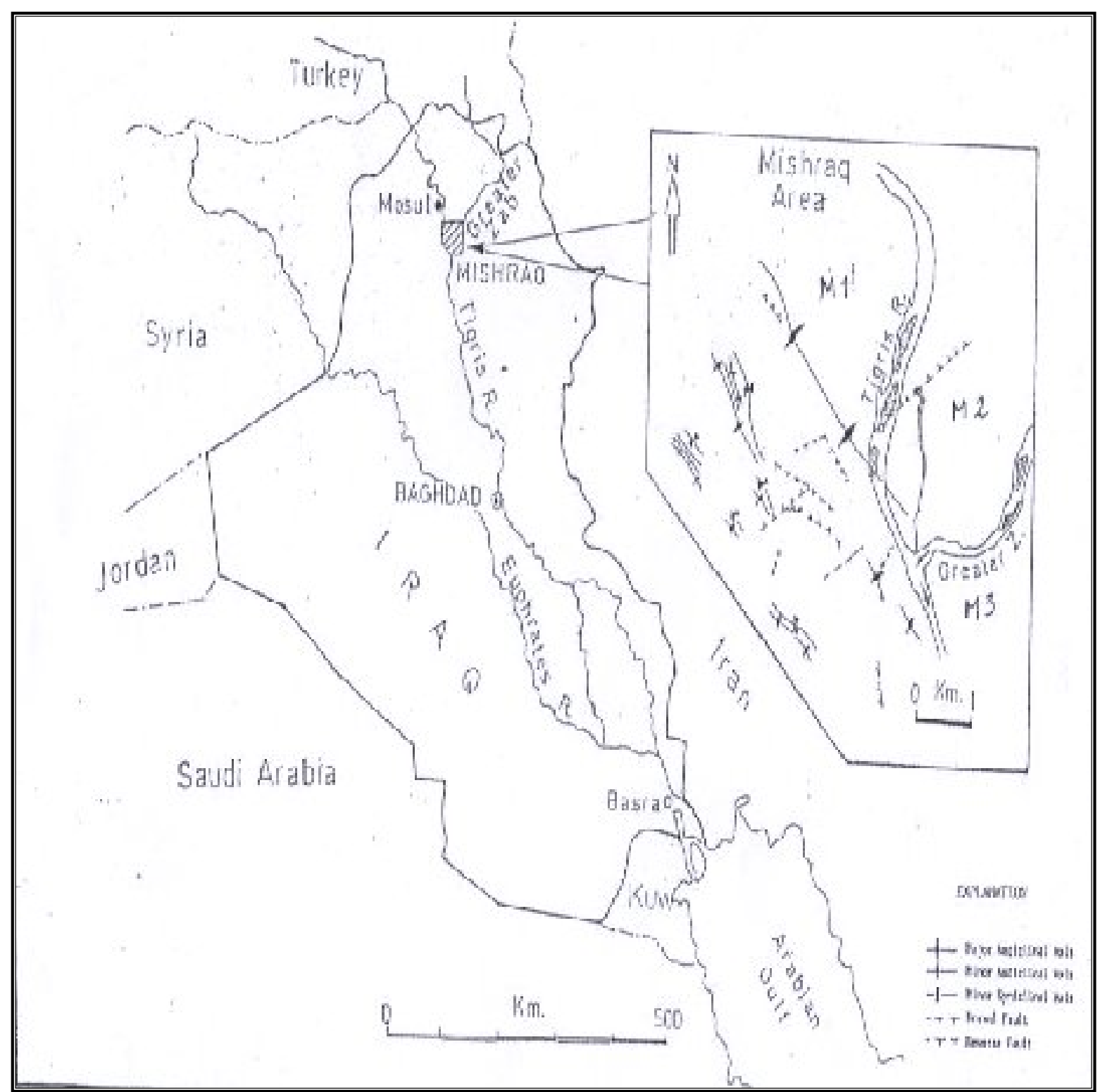

Fig.1 : Location map of the studied area 


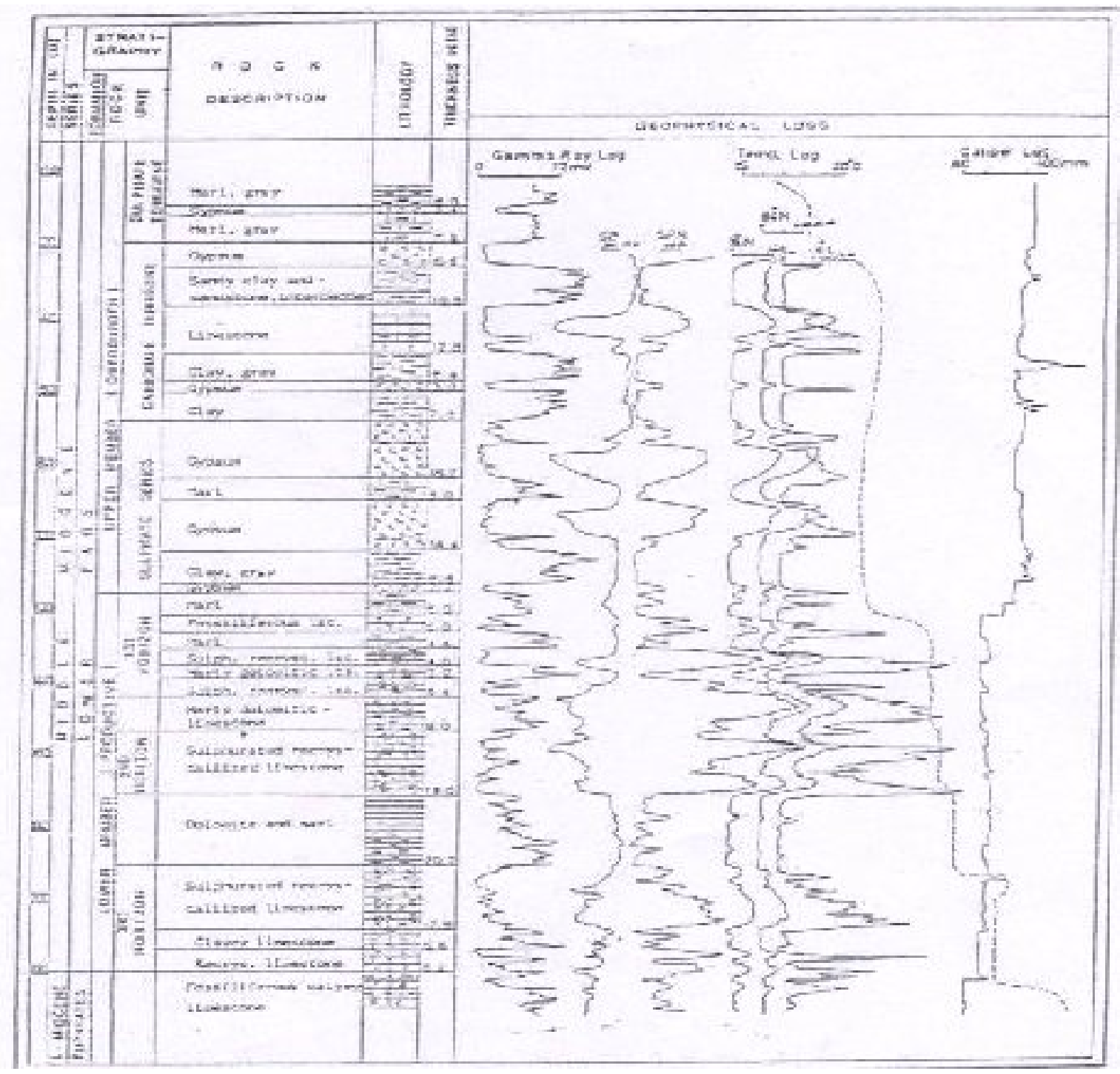

Fig. 2 : Geological log of the Al Fatha Formation at Mishraq Mine.

More over, the exploited sulphur increases the percentage of cavernosity, which causes the super heated water to flows in a large to the percentage of cavernosity, which allows to the super heated water flows by a large quantities to region of low pressure along the river bank, where a natural hydraulic continuity and drainage of underground water is existing in the region.

A solid screen technique was used at the front of exploitation near the river by the expertise of centrozap Co. (Mishraq Sulphur, 1972) to prevent the seepage of hot water. Characterized by drilling a large numbers of boreholes to a depth of $180 \mathrm{~m}$. along a distance of $150 \mathrm{~m}$. with $5 \mathrm{~m}$ apart from each other. Explosives were used to open the rocks between the boreholes and then a slurry composed of cement and other additives, to speed the setting time, were injected through boreholes to form concrete dyke to prevent the mine water to seep to the river. But this technique have failed because of the nature of the deposit and ineffective grouting, besides molten sulphur occurs in the region. The failure of this method was confirmed by the eruption of super-heated water accompanied by steam and 
molten sulphur inside the river, particularly when the injection rate reached to $20000 \mathrm{~m}^{3} / \mathrm{d}$ (Fig. 4).

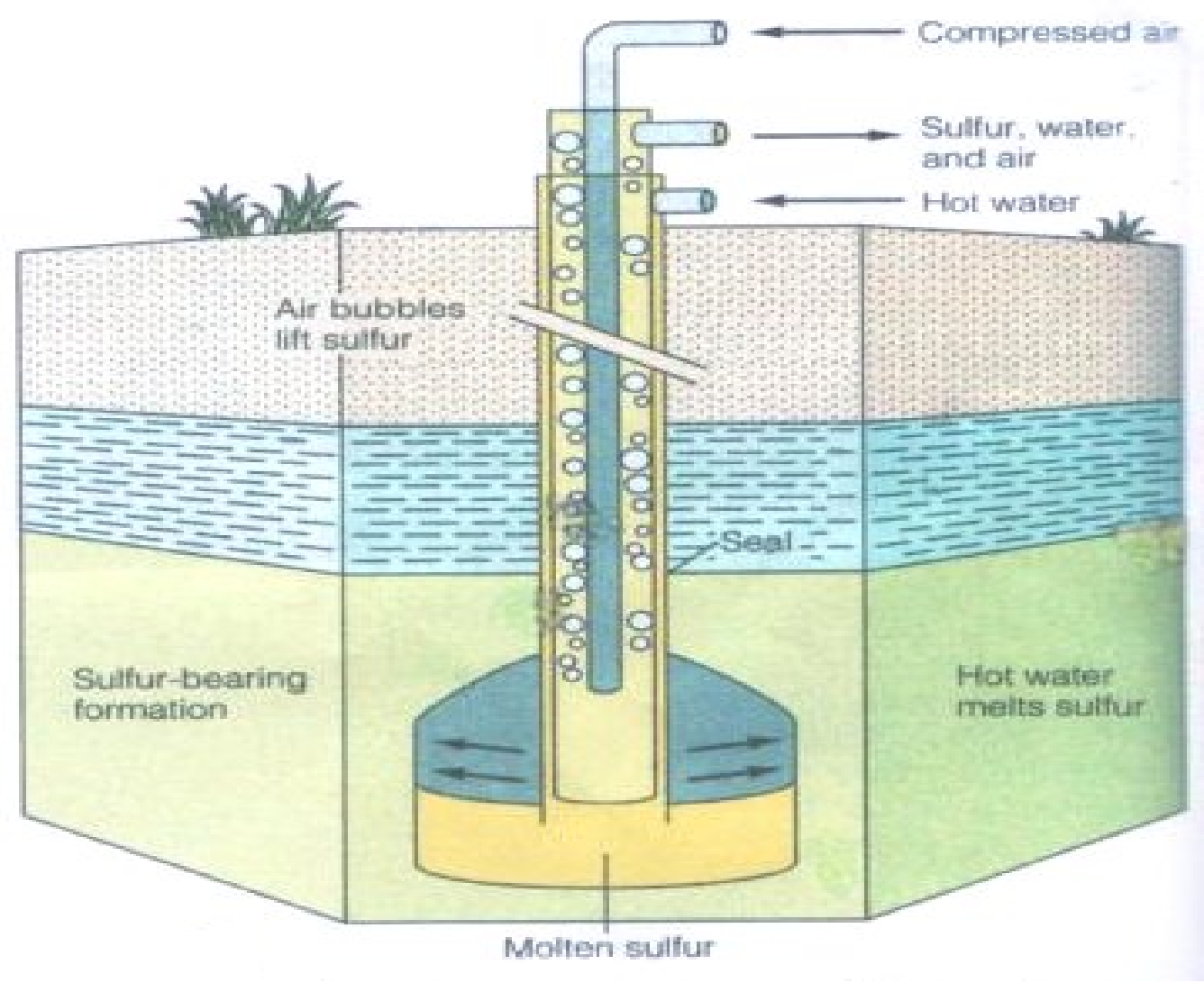

Fig. 3: Recovery of sulphur by means of the Frasch method after Conte et al, 1997

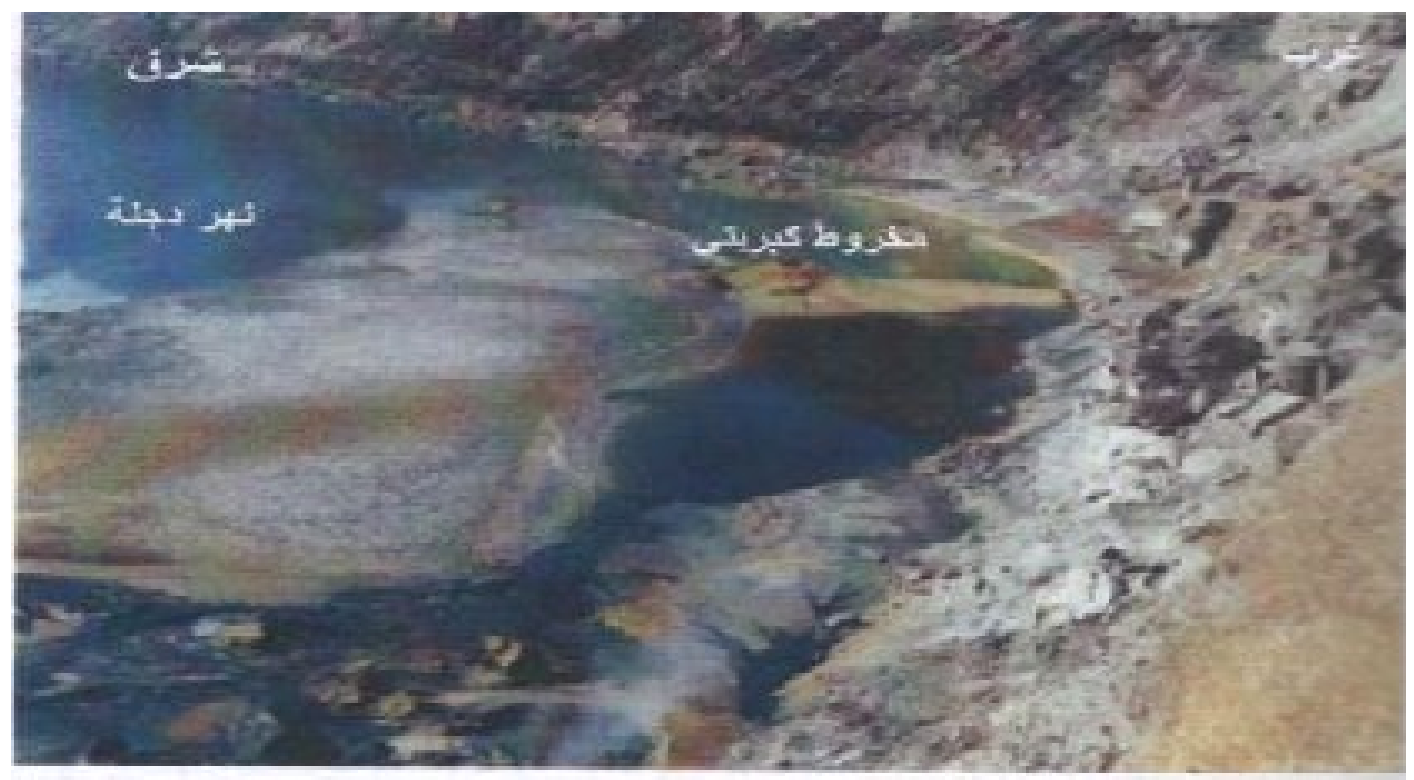

Fig. 4 : Location of super heating water and molten sulphur leakage in the River after (Saud, 2008) 


\section{HYDROGEOLOGY OF THE AREA}

The lithological nature of the Mishraq deposit, the alternation of permeable and impermeable beds, the tectonic activity in the deposit area, the geomorphological condition and the continuity with Tigris river, all influence the occurrence and depth of ground water.

The presence of marly beds in the upper part of the Euphrates limestone and relatively thick bed of clay with gypsum in the lower part of the upper member of $\mathrm{AL}$ - Fatha formation serves as confining beds for the complex multiple aquifer (Mahder - Bashi, 1986).

The transmissibility map show the high values of the more than $1000 \mathrm{~m}^{2} /$ day is concentrated at the center of the studied area indicating presence of cavity or channel developed along the fault plane (Fig. 5). The water level in two and three dimensional Fig. (6a) during the hot water injection show the groundwater flow toward the center of the studied area. This pattern of flow is chiefly toward the lowest point adjacent the river which has hydraulic continuity with the aquifer.

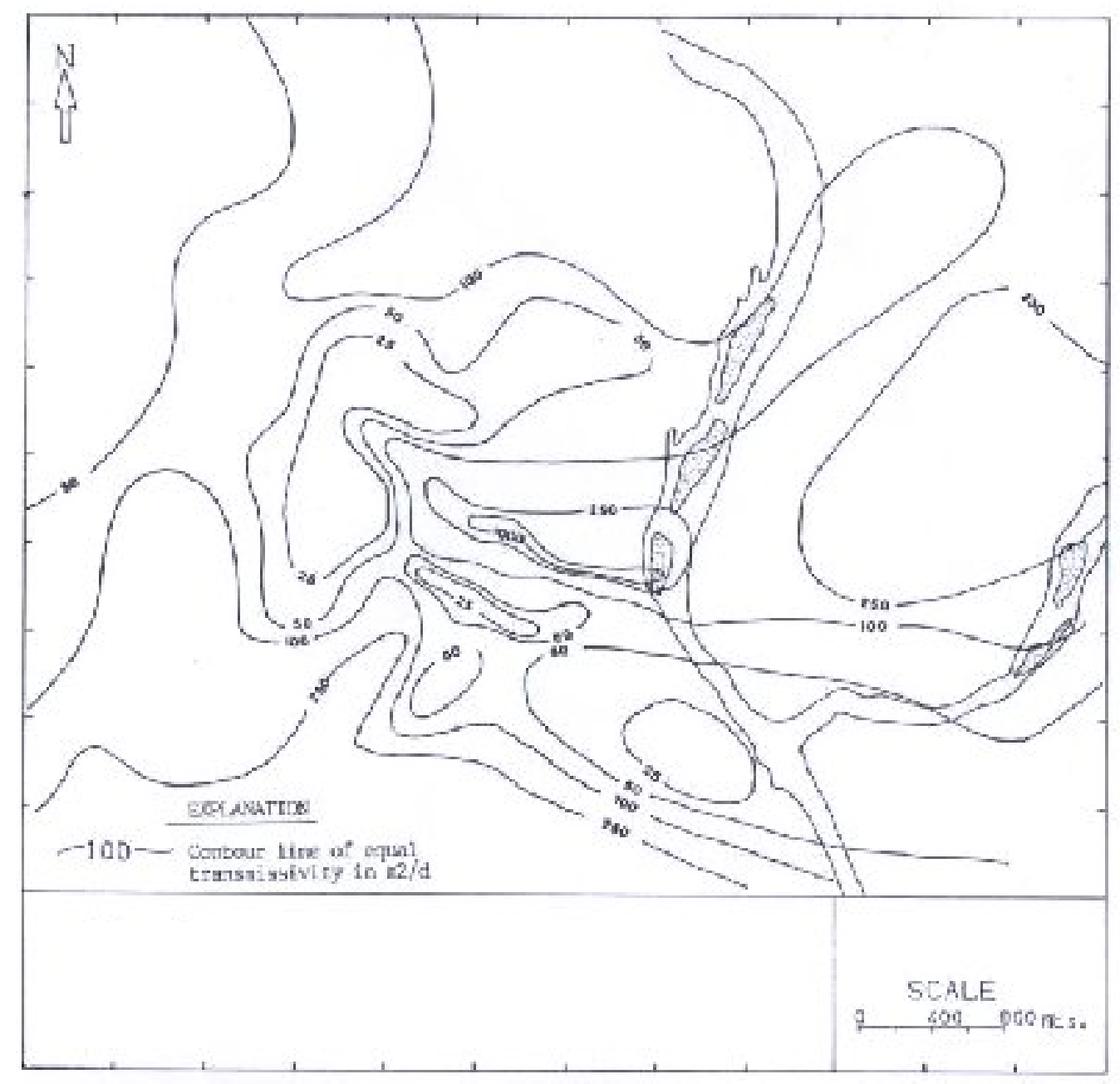

Fig. 5 : Transmissibility map in ( $\mathrm{m}^{2} /$ day) after Mahder - Bashi T. D. , 1986 
Utilizing Hydraulic Barriers to Reduce Leakage of Hot Water........ 


\section{TEMPERATURE DISTRBUTION}

Temperature measurements during production were accomplished by using geophysical temp. logging (Keys and Brown, 1978) for monitoring wells (Fig. 7) shows the isothermal map based on the maximum temperature measurements.

Examination of the temperature pattern show a small area of high temperate development around the injection sites, while long tongue (peek) of greater than $130^{\circ} \mathrm{C}$ detected along the fault plane, where the high transmissibility occurs. More over temperature of $97^{\circ} \mathrm{C}$ was also detected inside the river, which resulted from the eruption of molten sulphur and steam from the river bed. (Fig. 4).

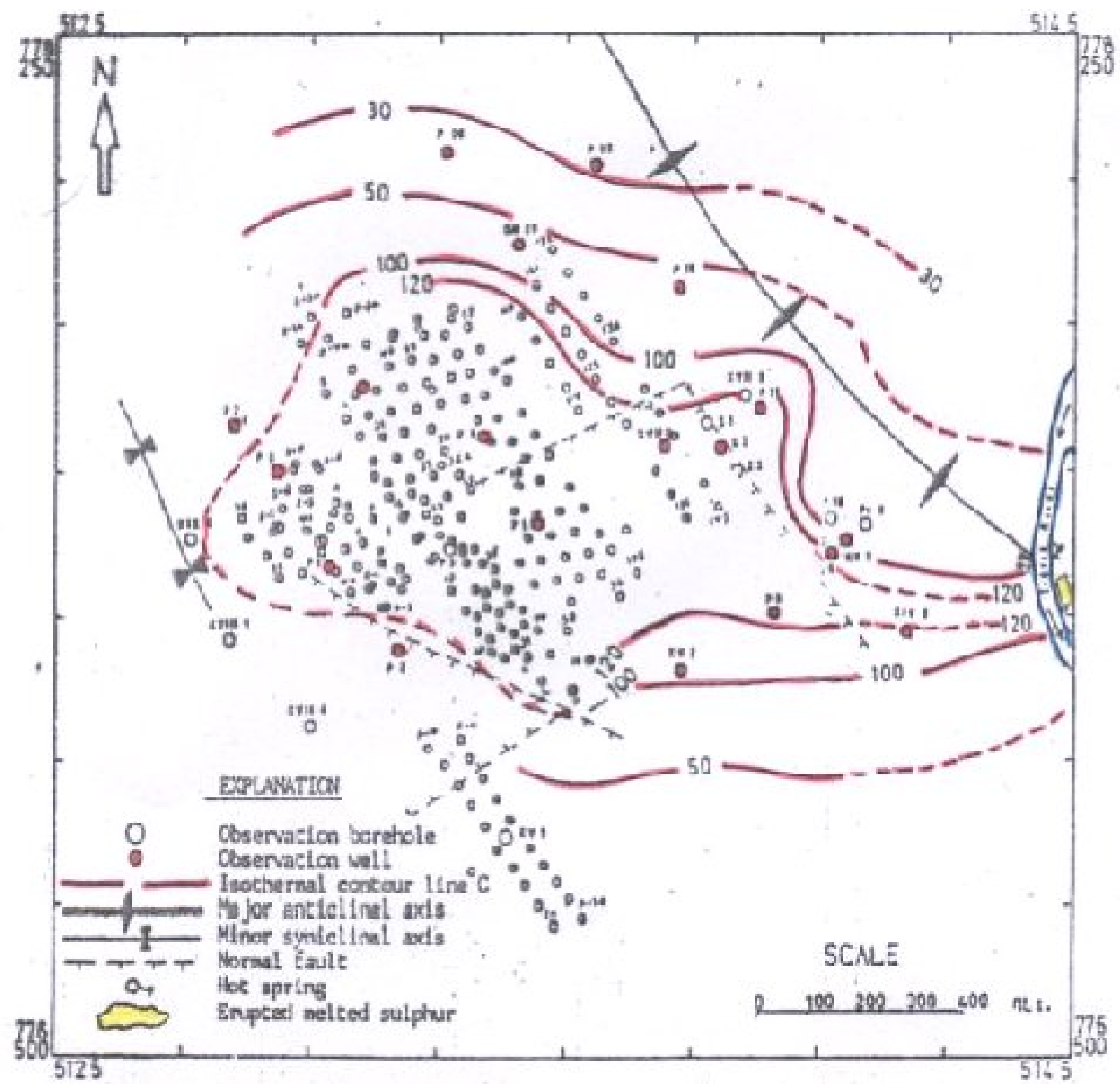

Fig. 7 : Isothermal map of the productive during production 


\section{DESCRIPTION OF HYDRAULIC BARRIERS}

The method involves construction of subsurface hydraulic barrier, to reduce the hydraulic gradient sufficiently and to prevent the out flow of hot water to the river. According to the author for functions can be obtained by this method:

1- reduction of hydraulic gradient which inturn reduces the water velocity.

2- establishment of injecting repression cone across the flow path of hot water there by limiting the area of leakage.

3- formation of a pressure ridge across the flow.

4- solidify the molten sulphur inside the caverns and the fractures.

A necessary condition for application of hydrostatic principle to this situation is the existence of two segregated fluids with a common interface, analogous, but is inverse situations to the Ghyben-Herzbege theory (Todd , 2005) of sea water intrusion . The general case of dynamic equilibrium between two immiscible fluids was investigated, by (Hubbert, 1953). According to the author, the dynamic relation between two fluids of different density also applicable not only to salt/fresh water condition (Hot, Cold water), but to other fluids assumed to be immiscible which exist in Mishraq mine condition. Therefore; the theory was adapted by the author to treat the leakage of hot water from sulphur/water bearing strata to the river and, to control and maintain the piezometric surface at balance with the injected hot water inside the deposit. The high injection rate of cold water reverses the leakage of hot water and move landward furtherinside the mine.

\section{DESIGN AND SITES OF THE HYDRAULIC SCREENS}

On the basis of temperature distribution, production, and transmissibility map, two sites for hydraulic screen have been chosen. The first site has been chosen near the river to rise the water level which in turn decreases the hydraulic gradient and the quantity of super-heated water flowing to the river. It consists of 8 wells located on a line perpendicular to the direction of flow, with $50 \mathrm{~m}$ a part from each other as shown in ( Fig. 8). 


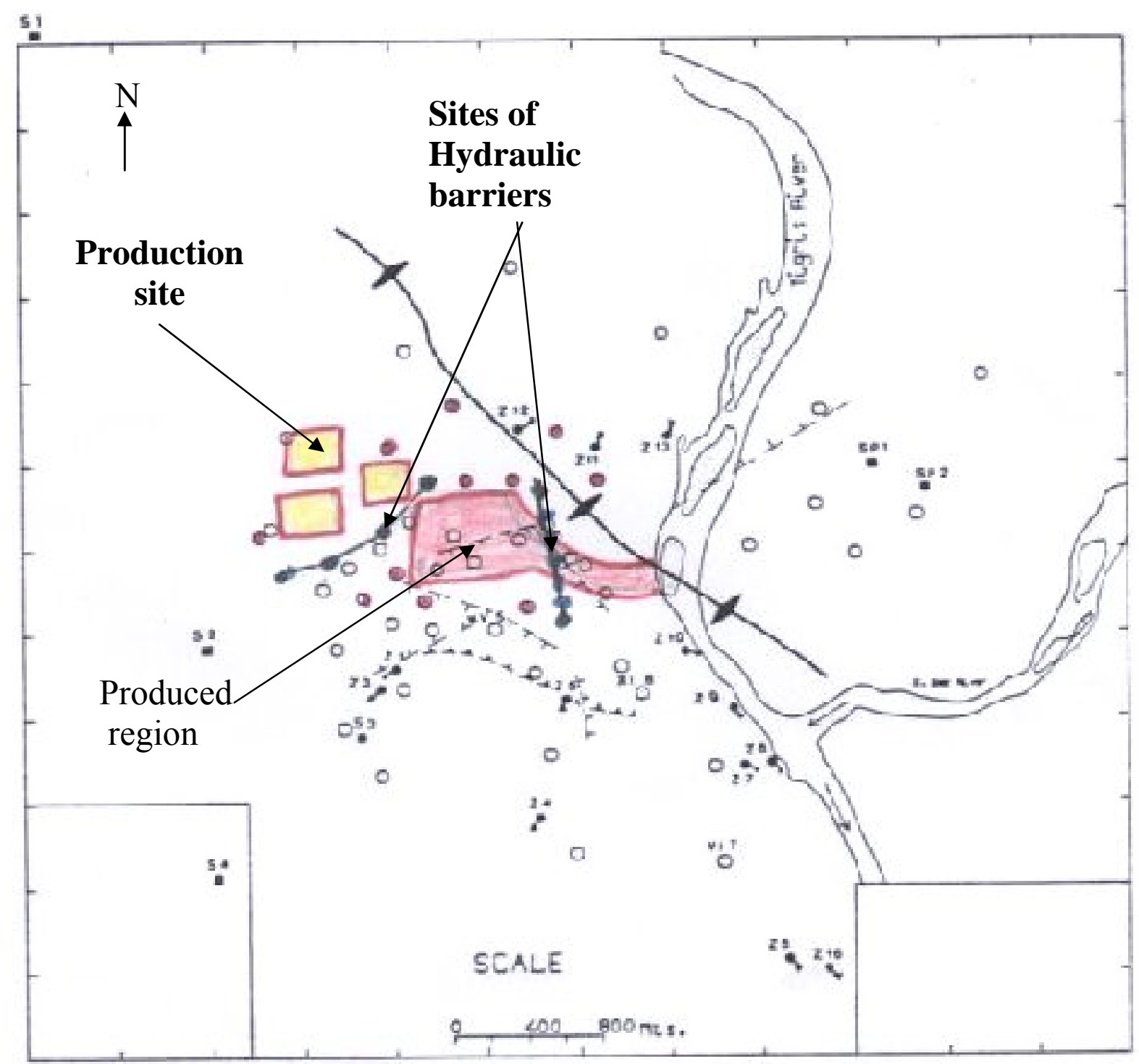

Fig. 8: Location map of the hydraulic barriers.

The second site has been chosen in a region inside the mine field between production site and a regions have already produced as shown in (Fig. 8), this screen consist of 4 wells with distance between them of about $100 \mathrm{~m}$.

The injection wells are designed by the author as shown in (Fig. 9). These wells designed in such a way that can be used for many purposes, such as injection , monitoring and production wells. Three inch pipes were installed inside $143 \mathrm{~mm}$ diameter well, with filter (screen) opened opposite the sulphur / water bearing zones of high permeability and maximum temperature. A packer manufactured locally used to seal the overburden rocks from the productive rocks (Fig. 10). The annulus between the wall of the well and the injection pipe left without cementation (grouting), this because the wells can be converted to other purposes. 


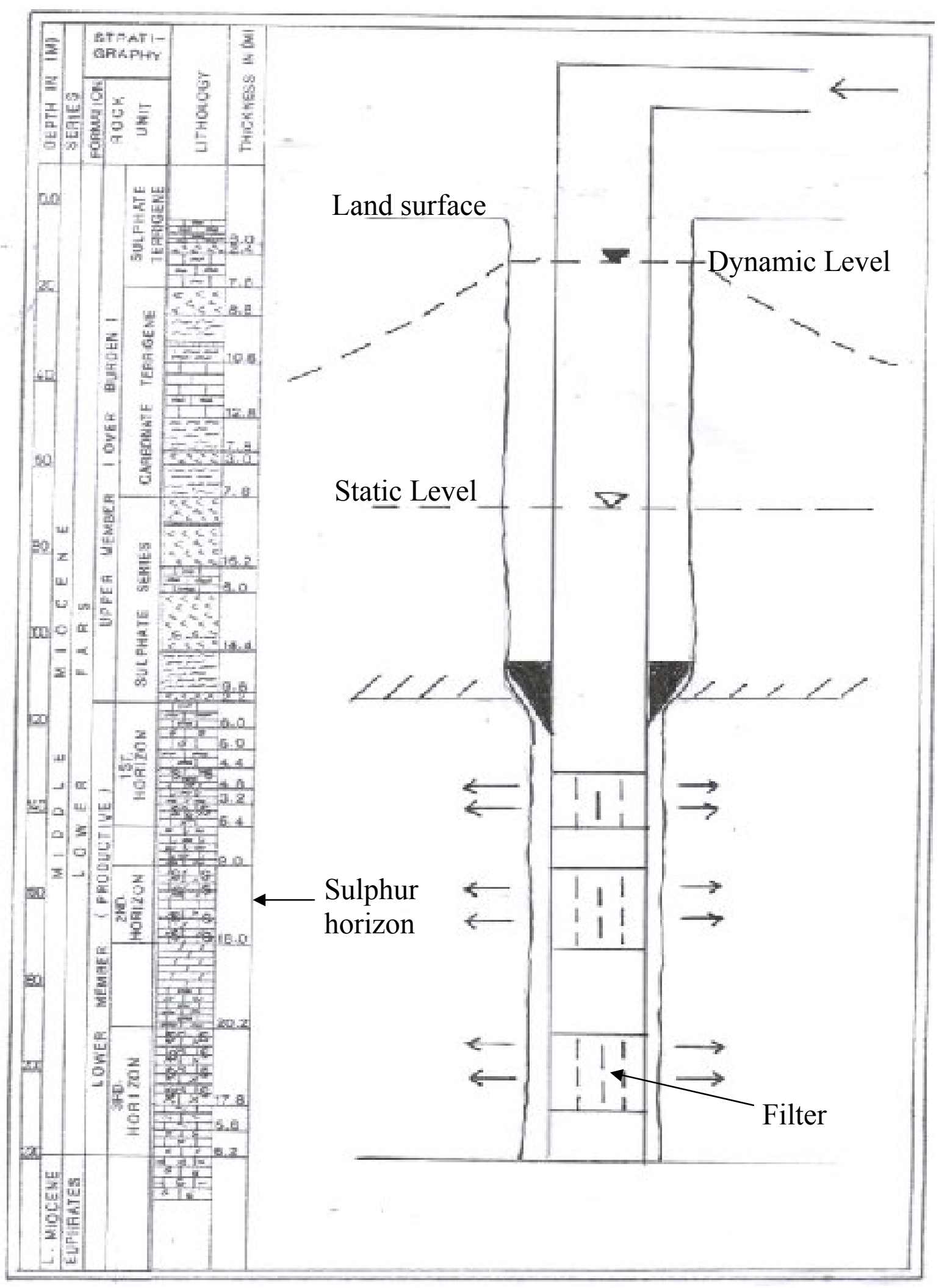

Fig. 9: Design of the hydraulic barrier well. 


\section{INJECTION OF COLD WATER}

Injection of cold water was achieved by withdrawal of raw water from the river using a pump of high capacity reaches up to $500 \mathrm{~m}^{3} / \mathrm{hr}$. The quantity required to raise the water level needed was calculated according to (Todd and Mays, 2005).

$h=\sum_{i}^{n} \frac{Q i}{2 \pi T} \ln \frac{R i}{r i}$

Where $\mathrm{h}$ the rise in water level in $\mathrm{m}$

Qi the quantity of water needed to inject for each wells $\mathrm{m}^{3} / \mathrm{d}$.

T transmissibility in $\mathrm{m}^{2} / \mathrm{d}$.

Ri radius of influence of repression cone of each well in $\mathrm{m}$ ri distance between the wells in $\mathrm{m}$.

The water level required also adjusted according to the level reach in the monitoring bore - holes around the screen (Fig. 10).

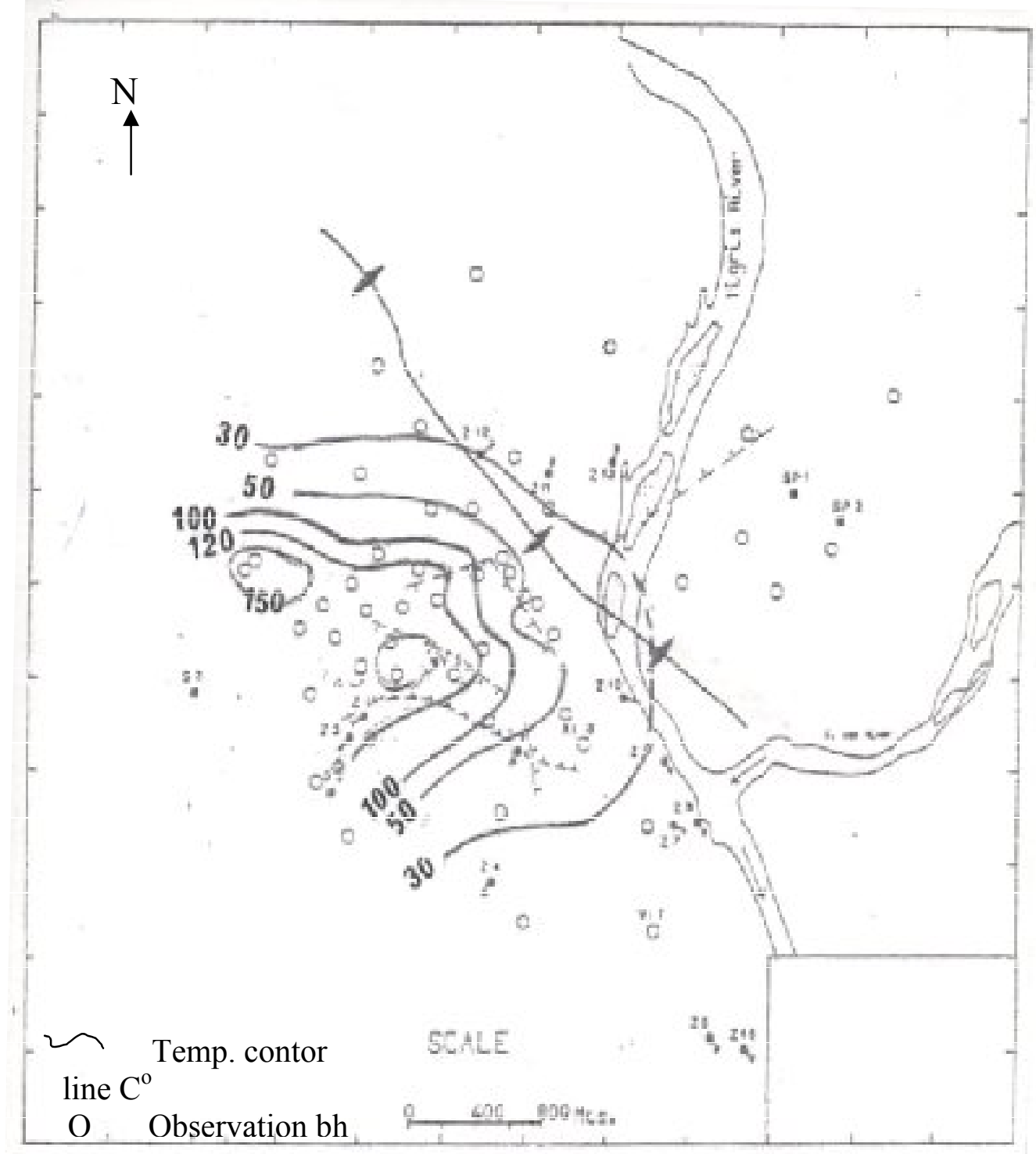

Fig. 10: Isothermal map after injection of cold Water in the Hydraulic barrier. 


\section{RESULTS}

As a result of cold water injection through the wells of first screen, the water level rose to $220 \mathrm{~m}$ above sea level which reverses the flow of hot water mineward and changed the pattern of flow to the south as shown in (Fig. 11). The temperature values obtained from the monitoring bore-hole show decreasing from $130^{\circ} \mathrm{C}$ to $50^{\circ} \mathrm{C}$ near the river as in (Fig. 10) where stopping the eruption of molten sulphur and steam from the river occur .

Injection of cold water in the second screen increased the production rate of sulphur from 1.5 ton $/ \mathrm{hr}$ to $4 \mathrm{ton} / \mathrm{hr}$ of each well, and dropped the water factor $\mathrm{Q}$ of water / ton of sulphur, (table 1) illustrate the stability and the increase of the rate of sulphur production, this is because the super-heated water confined by the pressure rise of cold water, and the whole energy of hot water was completely consumed for melting the sulphur without losses,

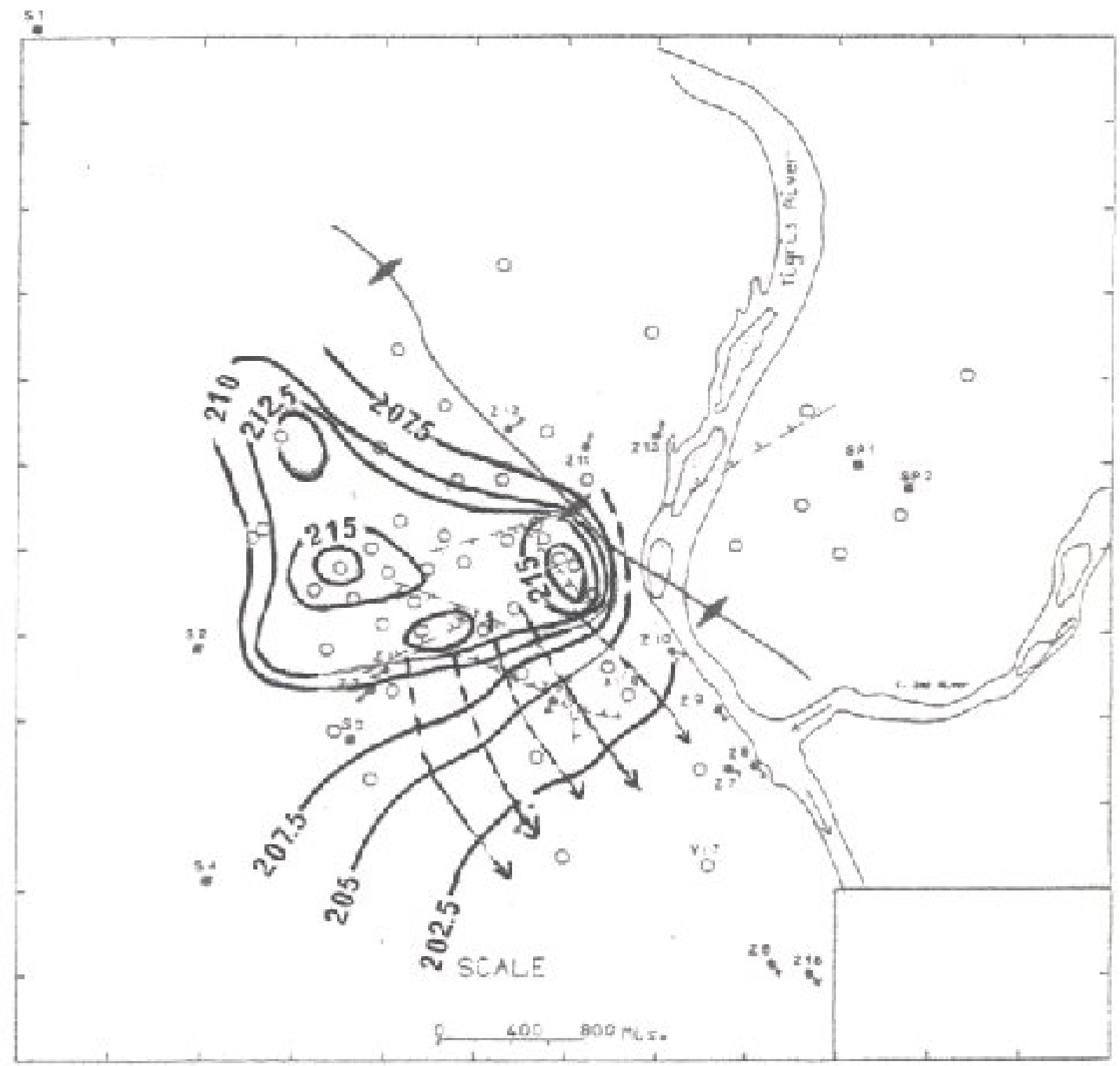

Fig. 11: Water level map m.asl. during injection of cold water. 


\section{DISCUSSION}

The results of this study, show, that the transmissibility and temperature maps indicated that the direction of flow of hot water is mainly along the faults planes, where the permeability and high hydraulic gradient toward the lowest pressure point exists. Injection of cold water through the line of wells of the first barrier built a repression cone of cold water with higher density than indigeneous water, this condition lead to form an enter face between the cold and hot water (Bear , 1979). The density variation between the fluids make the cold water of higher density to move toward the inland for about $200 \mathrm{~m}$. Distance of the injection site created a barrier against the hot water flow, this movement was confirmed by (AL-Juraisy, 2006). Changing the direction of hot water toward the south minefield and change in the temperature contor map and forming inside coning along the maximum transmissibility. This causes solidification of the flowing molten sulphur inside the cavities, which in turn reduced the quantity of water flowing to the river.

The second barrier has done the same phenomena, but here the cold water confined the hot water close the production wells and made the pressure inside the deposit to rise, which effected the daily production rate as shown in (table 1).

\section{CONCLUSION}

The method of injecting cold water through a line of wells as hydraulic barriers, was found to be very successful in controlling the leakage and steering the direction of flow of super-heated water, and stopping the molten sulphur to reach the river in such complicated geological and Hydrogeological conditions, where a large number of joints and faults planes occur, particularly near the river . Besides , this method approved to increase the productivity of sulphur from $1.5-5 \mathrm{ton} / \mathrm{hr}$ and stabilizing the rate of production as well as decreasing the general production factor from $20 \mathrm{~m}^{3} /$ ton to $12 \mathrm{~m}^{3} /$ ton. This method also considered very economic and flexible because there is possibility of converting the injection well, for monitoring purposes or as production wells where its needed. 
Table 1: Represent the quantity of hot water uses, production of sulphur, number of production wells before, and after the injection of cold water.

\begin{tabular}{|c|c|c|c|c|c|}
\hline $\begin{array}{c}\text { Production } \\
\text { Site }\end{array}$ & Date & $\begin{array}{l}Q \mathrm{~m}^{3} / \mathrm{d} \\
\text { of hot } \\
\text { water }\end{array}$ & $\begin{array}{c}\text { Produced } \\
\text { sulphur in } \\
\text { ton/day }\end{array}$ & $\begin{array}{c}\text { No. of } \\
\text { production } \\
\text { wells }\end{array}$ & Remark \\
\hline \multirow[t]{7}{*}{25} & $3 / \mathrm{I}$ & 5715 & 606 & 10 & \multirow{3}{*}{$\begin{array}{l}\text { Before } \\
\text { injection }\end{array}$} \\
\hline & $4 / \mathrm{I}$ & 6060 & 602 & 10 & \\
\hline & $5 / \mathrm{I}$ & 5995 & 707 & 10 & \\
\hline & $6 / \mathrm{I}$ & 6120 & 748 & 10 & \multirow{4}{*}{$\begin{array}{c}\text { After } \\
\text { injection }\end{array}$} \\
\hline & $7 / \mathrm{I}$ & 6100 & 828 & 9 & \\
\hline & $8 / \mathrm{I}$ & 6080 & 791 & 9 & \\
\hline & $9 / \mathrm{I}$ & 6120 & 756 & 9 & \\
\hline \multirow[t]{7}{*}{26} & $3 / \mathrm{I}$ & 4680 & 336 & 8 & \multirow{3}{*}{$\begin{array}{l}\text { Before } \\
\text { injection }\end{array}$} \\
\hline & $4 / \mathrm{I}$ & 4290 & 360 & 8 & \\
\hline & $5 / \mathrm{I}$ & 4320 & 368 & 8 & \\
\hline & $6 / \mathrm{I}$ & 4320 & 400 & 7 & \multirow{4}{*}{$\begin{array}{c}\text { After } \\
\text { injection }\end{array}$} \\
\hline & 7/I & 4320 & 429 & 7 & \\
\hline & $8 / \mathrm{I}$ & 4320 & 479 & 7 & \\
\hline & 9/I & 4320 & 489 & 7 & \\
\hline \multirow[t]{7}{*}{27} & $3 / \mathrm{I}$ & 8910 & 752 & 16 & \multirow{3}{*}{$\begin{array}{c}\text { Before } \\
\text { injection }\end{array}$} \\
\hline & $4 / \mathrm{I}$ & 8640 & 695 & 16 & \\
\hline & $5 / \mathrm{I}$ & 8640 & 865 & 16 & \\
\hline & $6 / \mathrm{I}$ & 8360 & 852 & 17 & \multirow{4}{*}{$\begin{array}{c}\text { After } \\
\text { injection }\end{array}$} \\
\hline & $7 / \mathrm{I}$ & 8160 & 895 & 15 & \\
\hline & $8 / \mathrm{I}$ & 8160 & 833 & 15 & \\
\hline & $9 / \mathrm{I}$ & 8160 & 875 & 15 & \\
\hline
\end{tabular}




\section{REFERENCES}

Al-Juraisy B. A., 2006. A correlation study of Geoelectrical properties of Mishraq sulphur field, Northern Iraq.

Bear J., 1979. Hydraulic of ground water McCraw - Hill, New York. 555 p.

Centrozap Co. 1971. Geological documentation of native sulphur deposit in Mishraq mine .

Conte D. J. , Thomson D. J. Moses L .L., 1997. Earth Science. An integrated perspective, $2^{\text {nd }}$ edition. Wmic Brown publishers, $332 \mathrm{p}$.

Feather Stone, R. C. and Al-Samarrie A. M., 1974. Sulphure Journal, No. 111, pp. 44-49.

Hubbert M. K., 1953. Entrapment of petroleum under hydrodynamic condition, Bull . Amer. Assoc. petrol . Geologist Vol. 37, pp. 1944 - 2028.

Jassim, S. Z. and Goff J. C., 2006. Geology of Iraq, published by Dolins prague and Moraviar Museum, Brno. $341 \mathrm{p}$.

Keys, W.S. and Brown R. F., 1978. The use of temperature logs to trace the movement of injected water, Ground Water, Vol. 16, No. 1, pp. 32 - 48.

Mahder - Bashi. T. D., 1986. solution mining of sulphur in the L-Fars formation at Mashraq in northern Iraq . Unpublished ph. D. Thesis, university of London $507 \mathrm{p}$.

Mishraq sulphur state Enterprise, 1972. Unpublished technological documentation of the tried exploitation of the pilot plant. part II, Mishraq library, Mishraq, Iraq.

Saud, Q. J. 2008. A comparative study before and after production stoppage from Al-Mishraq sulphur mine, south of Mosul central N. Iraq. Iraqi Bulletin of Geology and mining Vol. 4, No. 2, pp. 25 - 36.

Todd, D. K. and Mays L. W. 2005. Ground water Hydrology, $3^{\text {rd }}$ Edi, John Wiley and Suns, $636 \mathrm{p}$. 